\title{
Scientific Laboratory Information Management System: Tissue
} Bank

\author{
Chanchai McDonald ${ }^{* 1}$, Anand Kulkarni ${ }^{1,2}$ and Teeradache Viangteeravat ${ }^{1}$
}

Address: ${ }^{1}$ Department of Preventive Medicine, University of Tennessee Health Science Center, Memphis, TN 38163, USA and ${ }^{2}$ Department of Pathology, University of Tennessee Health Science Center, Memphis, TN 38163, USA

Email: Chanchai McDonald* - cmcdon12@utmem.edu

* Corresponding author

from UT-ORNL-KBRIN Bioinformatics Summit 2008

Cadiz, KY, USA. 28-30 March 2008

Published: 8 July 2008

BMC Bioinformatics 2008, 9(Suppl 7):P5 doi:10.1 I86/I47|-2 105-9-S7-P5

This abstract is available from: http://www.biomedcentral.com/I47I-2105/9/S7/P5

(c) 2008 McDonald et al; licensee BioMed Central Ltd.

\section{Tissue bank background}

A bio-repository to collect, process, archive, and distribute human tissues and fluids for research has been established in the Department of Pathology and Laboratory Medicine, UTHSC. The tissue bank currently provides HIPPA-compliant, de-identified, high-quality specimens to facilitate researcher queries for translational research. The bank is archiving large numbers of paraffin-embedded tissues, and is also performing comprehensive management of bio-repositories for institutional projects. The tissue bank at Department of Pathology (see Figure 1) is an example of utilizing the "Scientific Laboratory Information Management (SLIM) System" to have a more organized system and improve the overall efficiency of the collecting process for Tissue Bank.

The effective scientific data retriever will provide fast access to a wide range of scientific data via the Web or directly from an application, facilitating data sharing with other research teams and the general public. Research teams can download data files from a large data provider, augment this "mini-archive" with their own datasets, and make the whole heterogeneous data collection accessible via the Web.

Users can interactively browse the contents of a file, examine a subset of the data, view a thumbnail image of the data, and download the desired subset. The SLIM system can be coupled with services for extracting, indexing, and searching metadata to create a complete repository service.

\section{Conclusion}

The effective scientific data retriever will enhance the effectiveness of scientific laboratory management. It will provide an application to collect laboratory materials, tools, and budgets for the scientific laboratory. The strategies for creating an application depend upon the nature of particular scientific research. 


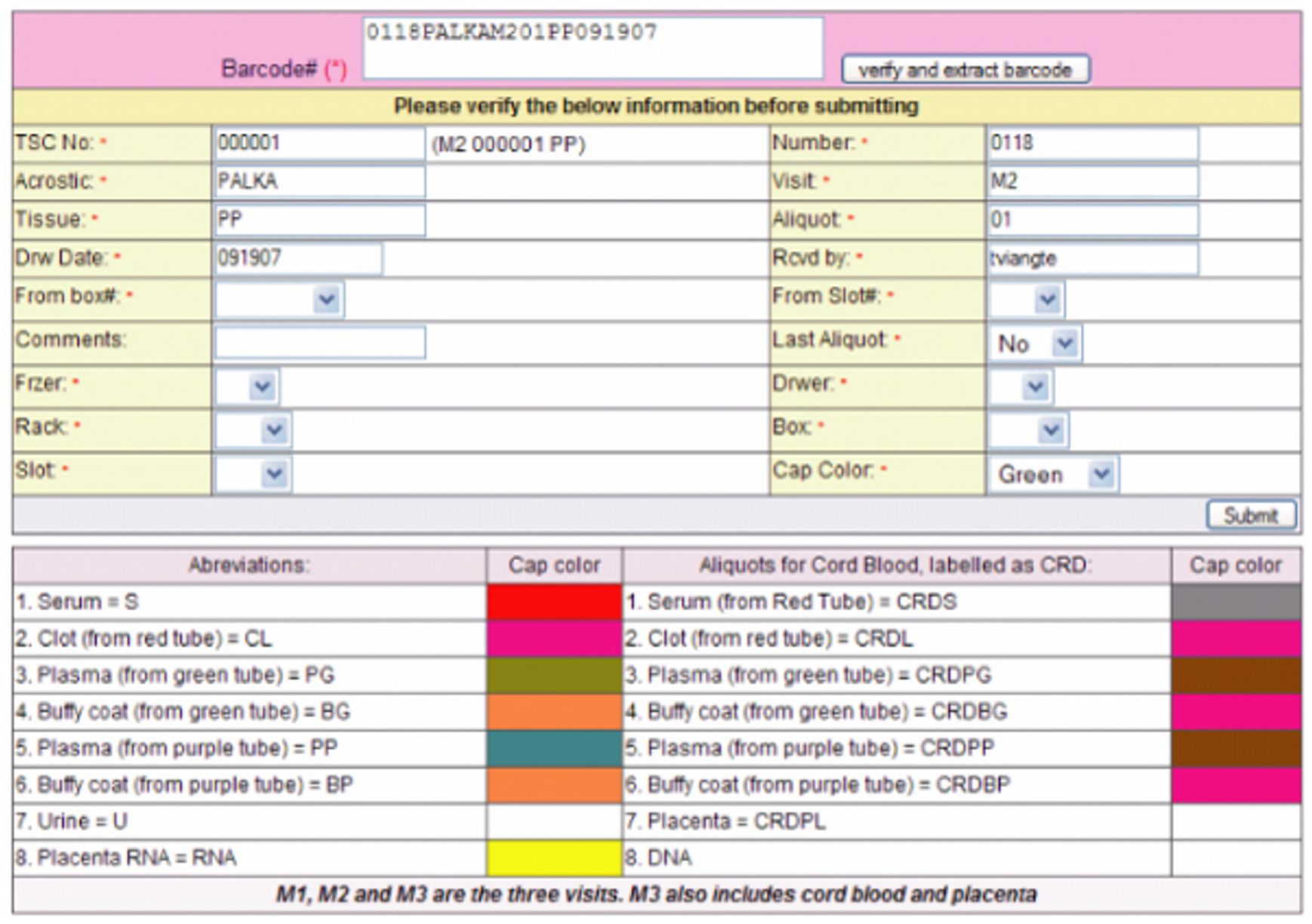

\section{Figure I}

Screenshot of the SLIM system for a tissue repository.

Publish with Biomed Central and every scientist can read your work free of charge

"BioMed Central will be the most significant development for disseminating the results of biomedical research in our lifetime. " Sir Paul Nurse, Cancer Research UK

Your research papers will be:

- available free of charge to the entire biomedical community

- peer reviewed and published immediately upon acceptance

- cited in PubMed and archived on PubMed Central

- yours - you keep the copyright
BioMedcentral 